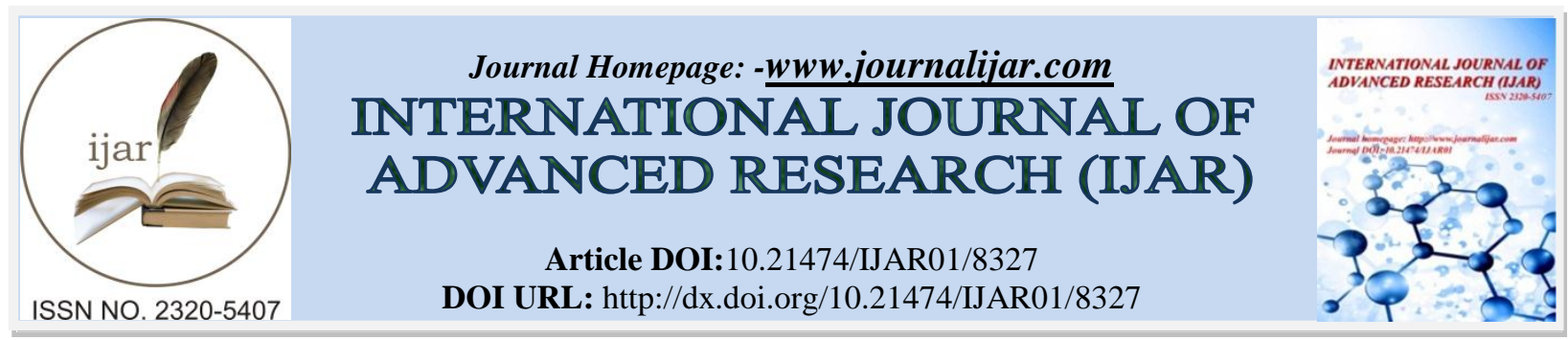

RESEARCH ARTICLE

\title{
COMPARATIVE EVALUATION OF TENSILE BOND STRENGTH AND GAP WIDTH BETWEEN SILICONE BASED SOFT LINER AND HEAT-POLYMERIZED, LIGHT POLYMERIZED AND INJECTION-MOLDED PERMANENT DENTURE BASE MATERIALS.
}

\author{
Pallavi N. T ${ }^{1}$, Regish K. M $^{2}$, Basavaraj S. Salagundi ${ }^{3}$, Rupesh P. L ${ }^{4}$, Jyothi K. S. ${ }^{5}$, Unni Pympallil ${ }^{6}$ and \\ Bhavana B. $\mathbf{L}^{6}$. \\ 1. MDS, PG student, Department of Prosthodontics, Coorg institute of dental sciences, virajpet. \\ 2. Ph.d, Reader, Department of Prosthodontics, Coorg institute of dental sciences, virajpet. \\ 3. MDS, HOD \& Professor, Department of Prosthodontics, Coorg institute of dental sciences, virajpet. \\ 4. MDS, Chairperson, Department of Prosthodontics, Coorg institute of dental sciences, virajpet. \\ 5. MDS, Department of Prosthodontics, Annoor dental college and hospital Muvathupuza, Kerala. \\ 6. MDS, Senior Lecturer, Department of Prosthodontics, Coorg institute of dental sciences, virajpet.
}

\section{Manuscript Info}

Manuscript History

Received: 04 November 2018

Final Accepted: 06 December 2018

Published: January 2019

Key words:-

Light-activated urethane dimethacrylate,

Tensile bond strength, Gap width,

Resilient denture liners.

\section{Abstract}

Denture liners are polymers used on the intaglio surface of the denture. Adhesive failure can create environment for bacterial growth, staining, and failure of lining materials.Hence, the integrity of the junction needs to be evaluated because two materials polish differently.Therefore, this study compares the tensile bond strength and gap width between soft liner to heat-polymerized, injection-molded and light polymerized acrylic resins.

Materials and Methods:-Ten dumbell shaped specimens for tensile bond test and square shaped specimens for gap width were fabricated with the metal mold. Putty index of dumbell shaped mold with the rectangular die in centre and two metal blanks were made. The specimes were placed in the index, adhesive was applied onto the bonding surface and soft liner was added. Tensile bond strength was determined in universal testing machine and gap width was observed under scanning electron microscope.Specimens were divided into 3 groups for tensile bond test and for gap width: T1, G1 heatpolymerizing; T2, G2 injection-molded; T3, G3 light activated denture base resins.Statistical analysis of the obtained data was done by ANOVA and post-hoc Tukey's test.

Results:-Therewas significant difference in the tensile bond strength among the three groups $(\mathrm{p}<0.05)$, and the mean gap width was not significant between G1 and G3 group and highly significant value was seen among $\mathrm{G} 1$ and $\mathrm{G} 2 ; \mathrm{G} 2$ and $\mathrm{G} 3$ groups $(\mathrm{p}<0.05)$.

Conclusion:-Mollosil B bonds best with heat-polymerized denture base material and least gap with between denture base and soft liner.

Copy Right, IJAR, 2017,. All rights reserved.

Corresponding Author:-Pallavi N. T.

Address:-MDS, PG student, Department of Prosthodontics, Coorg institute of dental sciences, virajpet. 


\section{Introduction:-}

Over the past century, polymethyl methacrylate (PMMA) denture base resin has been the first choice of clinicians for denture fabrication due to its low cost, adequate esthetic properties, and ease of manipulation (Tugut et al, 2016). Apart from polymethyl methacrylate (PMMA) various materials and fabrication techniques have been employed for denture construction, which includes vulcanized rubber (vulcanite), polycarbonate, nylon, and urethane dimethacrylate (UDMA) resin (Akin et al, 2013). Thermoplastic resins (Polyamide, Polyethylene Terephthalate Copolymer and Polycarbonate) are used for RPDs without metal clasps because these thermoplastic resins have better esthetics and higher elasticity than heat-polymerizing denture base resin (PMMA) (Hamanaka et al, 2017), (Hamanaka et al, 2013).Furthermore, light-activated UDMA resin exhibited significantly improved mechanical properties such as transverse strength, impact strength, surface hardness, flexural modulus, and flexural strength, when compared to PMMA denture base polymers (Machado et al, 2007), (Diaz-Arnold et al, 2008).Light activated UDMA resins were developed to eliminate contact allergies, laboratory vapors, and traditional, lengthy investing, flasking and boil-out processes, and water bath polymerization used with the PMMA materials (Ahmad et al 2009), (Razavi et al 1990).

Denture relining is defined as procedure used to resurface the tissue side of denture. It eliminates the need for making new dentures for the patient when changes are minimal and existing denture is in a relatively good condition. These chairside reline materials allow dentist to reline removable prostheses directly in mouth. Two types of chair side denture relining materials are used: Hard and soft reliners. Soft reliners are divided into four groups based on chemical structures: plasticized acrylic resins (chemical or heat cured), vinyl resins, rubbers (polyurethane and polyphosphazine type) and silicone rubbers (Lau et al, 2014). Soft or resilient liners are preferred for sensitive mucosal tissues (Aydin et al, 1999).

Soft liners have several problems like loss or varying degree of softness, colonization with Candida albicans, staining, porosity, poor tear strength and lack of color stability. One of the serious problems is the failure of adhesion between the soft liner and the denture base. Therefore, measurement of bond strength is very important(Mutluay and Ruyter, 2005), (Mittal et al, 2016).

The mechanical properties of soft relining materials and their bonding characteristics have been evaluated by various test methods. There are three widely accepted methods for testing adhesion of denture soft liners to denture base polymers: peel, lap-shear and tensile testing. For testing the adhesion between the soft lining materials and PMMA denture base polymer, the tensile test method was preferred. American Society described this method for Testing and Materials (ASTM) and data obtained from such samples were found significant for testing the effectiveness of different processing techniques and various adhesive systems (Akin et al, 2013).

A scanning electron microscope (SEM) is commonly used for this purpose because it allowed specimens to be visualized in 3 dimensions and has been shown to be an effective tool for visual and qualitative evaluations of polished and processed dental materials (Al-Athel and Khier,1997).

So, it becomes essential to determine the tensile bond strength of heat-cured, injection-molded and light activated denture base materials to soft liner material and also determines the gap width between them after finishing and polishing procedures.

\section{Materials and Methods:-}

The three denture base materials evaluated were - Heat polymerizing denture base resin (Heat cure, Dental products of India, Mumbai, India); Injection molded denture base resin [Polyamide (PA12), Valplast universal co. ltd, Tokyo, Japan] and Light activated denture base resin (Eclipse; DENTSPLY trubyte, New York, United States of America) with the Soft denture liner (Mollosil B DETAX, Gmbltand co. kg, Ettinger, Germany).

Three different types of test specimens were made (Fig. 1):

1. For the evaluation of tensile bond strength a dumbbell shape split mold of dimension $82.5 \times 19 \times 3.2 \pm 0.4 \mathrm{~mm}$ was made according to ASTM specification D638-02a.

2. For the evaluation of gap width square shape metal blank of dimension $4 \times 4 \times 1 \mathrm{~mm}$ was made.

3. For the bonding of soft liner rectangular shape metal die of dimension $3 \times 3 \times 13 \mathrm{~mm}$. 


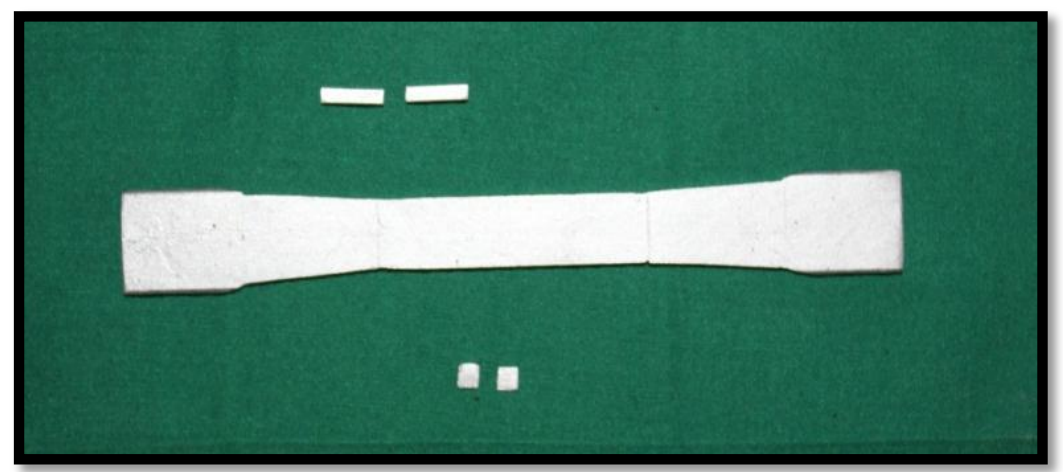

Fig 1:-Rectangular metal die, dumbell shape split metal mold,and square metal blank.

The specimens were divided into three groups T1, T2 and T3 for tensile bond test and G1, G2 and G3 for gap width according to the type of denture base material:-

$\mathrm{T} 1$ (heat polymerizing denture base resin $-\mathrm{n}=10$ samples)

$\mathrm{T} 2$ (injection molded thermoplastic resin $-\mathrm{n}=10$ samples)

T3 (light activated denture base resin $-\mathrm{n}=10$ samples)

G1 (heat polymerizing denture base resin $-\mathrm{n}=10$ samples)

G2 (injection molded thermoplastic resin $-\mathrm{n}=10$ samples)

G3 (light activated denture base resin $-\mathrm{n}=10$ samples)

Ten specimens were prepared using the split mold and ten secimens with square metal mold as follows.

\section{Heat polymerizing denture base resin: Group T1 and G1:-}

The molds were coated with petroleum jelly and were invested in dental flask using two pour technique (fig 2). Once the plaster sets the flask was opened and molds were removed. Separating media was applied and the mold space was packed with Polymethylmethacrylate denture base material. The flasked was clamped and polymerized with short curing cycle. The flask was allowed to bench cool followed by deflasking (fig 3). The specimens were trimmed with tungsten carbide bur and polished.

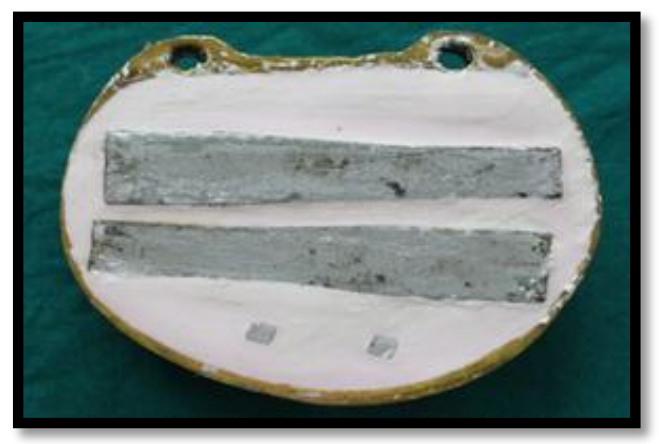

Fig 2:-Investing the split mold.

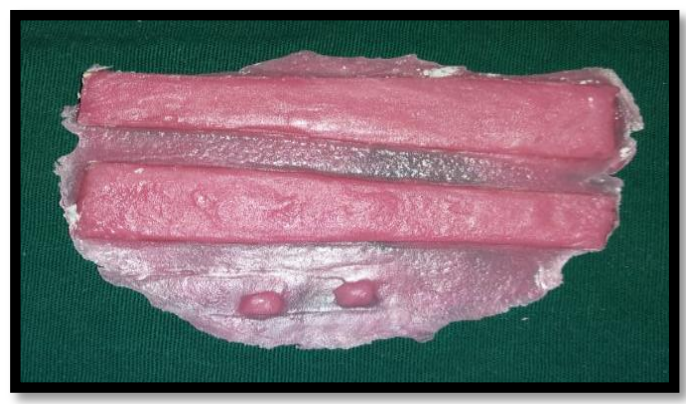

Fig 3:-Specimens after deflasking square metal blank. 


\section{Injection molded thermoplastic resin: T2 and G2:-}

A putty index of both the molds were made. 20 split wax specimens and 10 square specimens were made with the help of putty mold (fig 4). The wax specimens were invested in flask. Separating media was applied on the stone and flask was locked, the plaster was then made to flow until the flask is completely filled. Dewaxing was done in water bath and excess wax was removed (fig 5). The two flask halves were locked with locking clamps. The material was mixed and loaded to the injector according to manufacturers instructions. The flask was placed in polymerization unit. The hot flask was removed from injector and cooled under cold running water for 15 min. Divesting was performed (fig 6). The polymerized ivobase material was finished with gross cut tungsten carbide burs and polished.
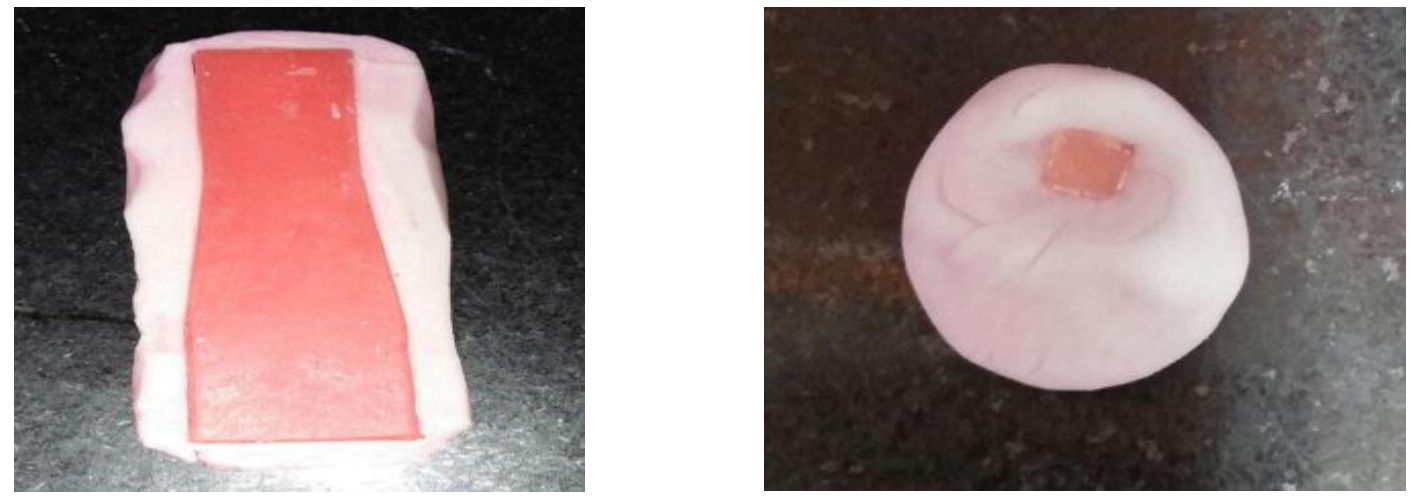

Fig 4:-Wax patterns made with the putty index.

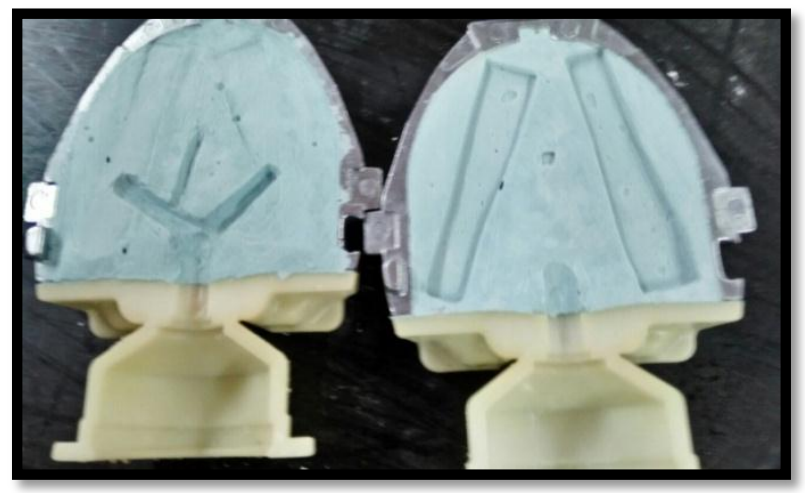

Fig 5:-Dewaxing done to create mold space for injection molded denture base material.

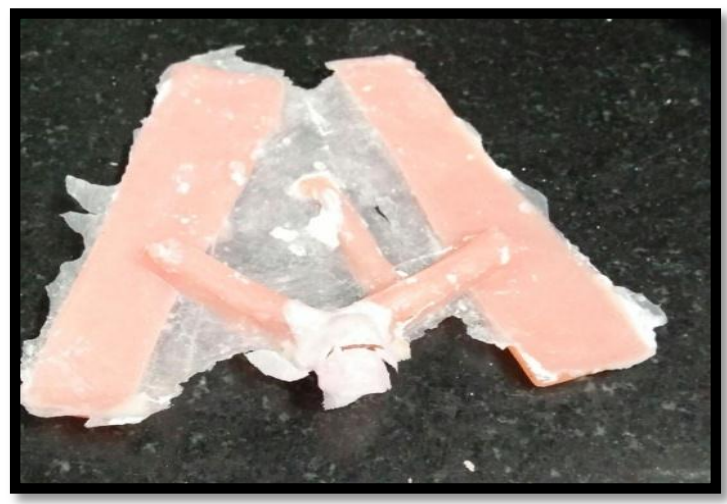

Fig 6:-Injection molded denture base samples divested. 


\section{Light activated denture base material: Group T3 and G3:-}

Light activated materials were molded and loaded into the putty index and pressed with glass slab to remove excess. These samples were polymerized with visible light cure with blue light of 400-500nm (Fig 7). After polymerization the materials were finished and polished.

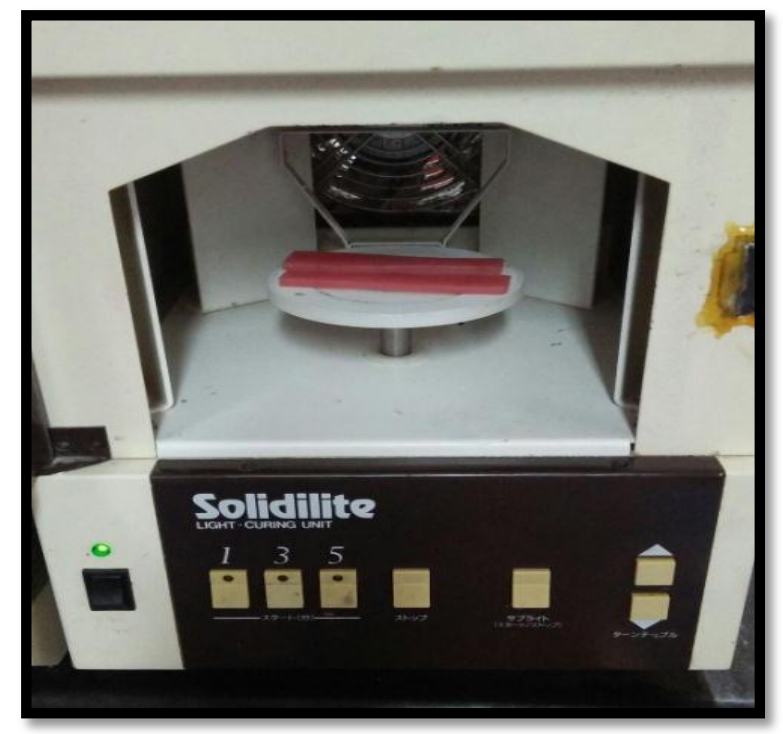

Fig7:-Polymerization with visible light cure.

\section{Application of soft liner:-}

Specimens for tensile bond strength test (fig 8,9,10);-

The rectangular metal mold was placed between the two split molds and a putty index of this was made. The adhesive was applied onto the surface of both the split specimens and let it dry for approximately $1 \mathrm{~min}$. The split specimens were both placed on the putty mold. The bubble free soft liner material was placed in between the two split specimens where adhesive was applied and let to set for $7 \mathrm{~min}$. The excess material was removed and the surface was made smooth and polishing liquids lustrol gloss varnish was taken on a dapen dish and mixed homogenously in the ratio of 1:1 and brushed on the surface for smoothening on trimmed surface.

\section{Specimens for gap width:-}

Two square-shaped metal mould were placed together and putty index was made. The denture base specimens were placed in the putty index and adhesive was applied onto the bonding surface. The bubble free material was placed on the specimen where adhesive was applied and let to set for $7 \mathrm{~min}$. excess material was removed, surface was made smooth and polishing liquid lustrol gloss varnish was brushed. Both the Specimens were maintained in distilled water at $37^{0} \mathrm{C}$ for 7 days to simulate use in oral environment.
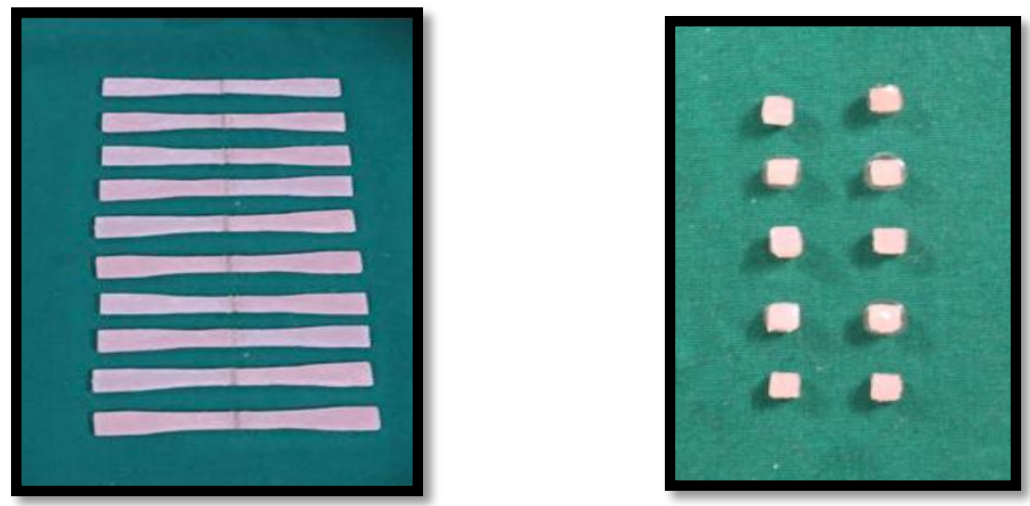

Fig 8:-Heat polymerized specimens for tensile bond test and SEM 

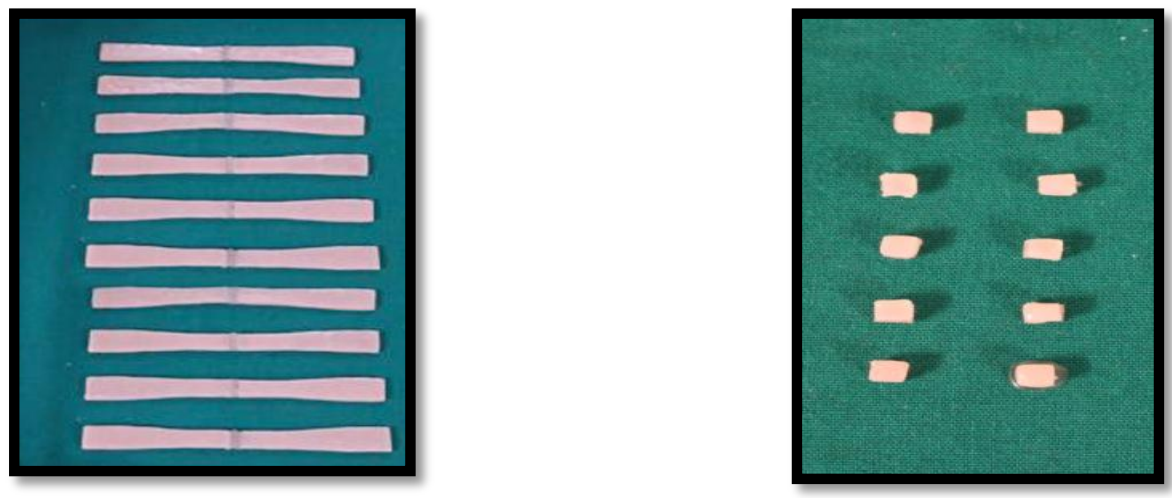

Fig 9:-Injection molded specimens for tensile bond test and SEM
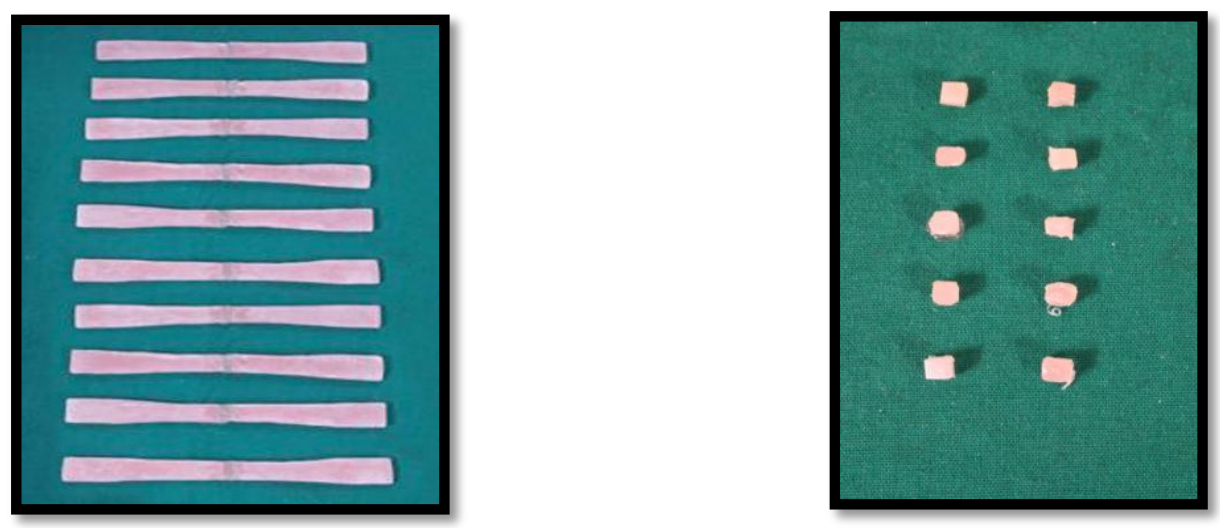

Fig 10:-Light activated specimens for tensile bond test and SEM

\section{Tensile bond strength test:-}

Tensile bond strength of the material was determined using universal testing machine by attaching both ends of the flat dumbbell specimens to the jig and subjecting them to tensile force at a crosshead speed of $5 \mathrm{~mm} / \mathrm{min}$ until failure occurs (Fig 11). The tensile bond strength values of each specimen were calculated with the following formulae:

$$
\mathrm{S}=\mathrm{F} / \mathrm{A}
$$

Where, S-bond strength (expressed in Megapascal) F-maximum force (Newton) A-cross sectional area (square millimeters)

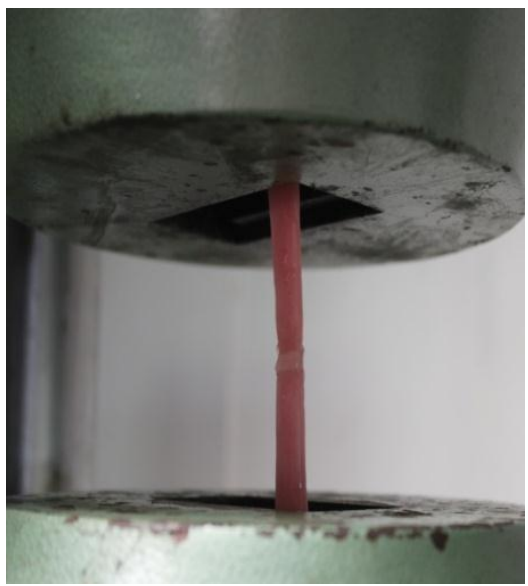

Fig 11:-Universal testing machine 


\section{Scanning electron microscope:-}

The square specimens were observed under scanning electron microscope and the gap at the interface between the soft liner and the denture base material were measured in micrometer $(\mu \mathrm{m})$. The images obtained are depicted in Fig $12 \mathrm{~A}, \mathrm{~B}$ and $\mathrm{C}$.

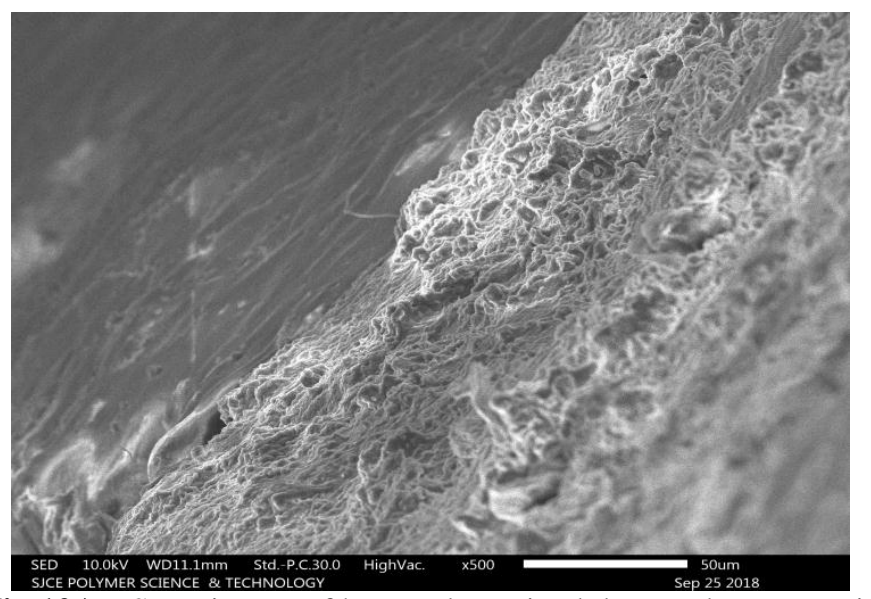

Fig 12A:- SEM image of heat-polymerized denture base material

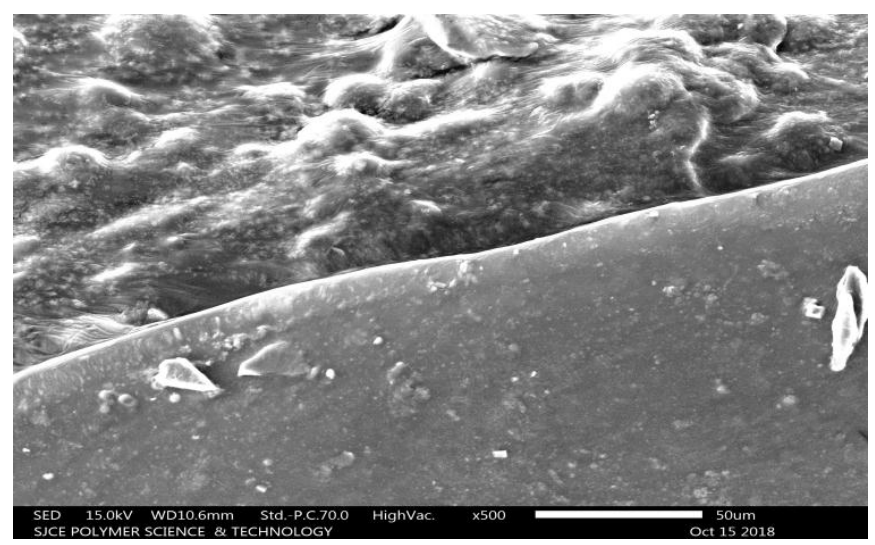

Fig 12B:-SEM image of injection- molded denture base material

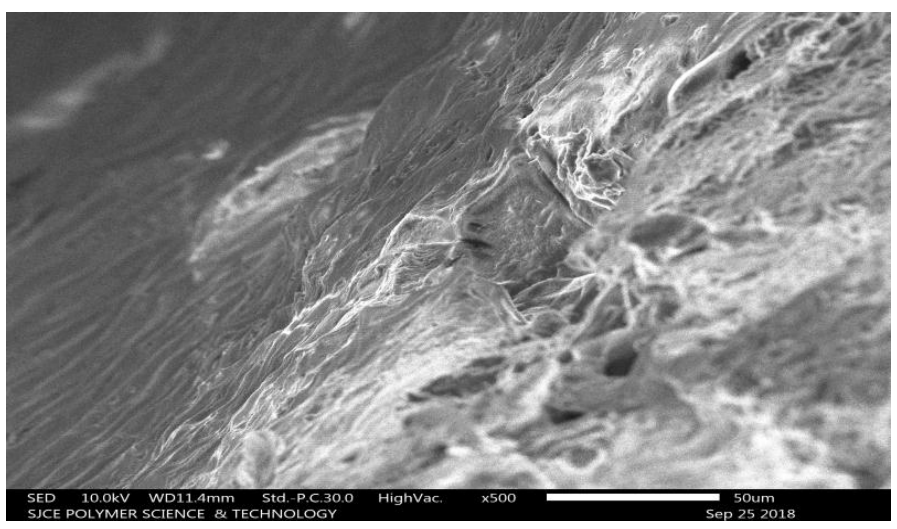

Fig 12C:-SEM image of light activated denture base material

\section{Statistical analysis:-}

Statistical analysis of the obtained data was done by one-way (ANOVA) and Post-hoc Tukey's test. 


\section{Results:-}

The results show that there is significant difference in the tensile bond strength among the three groups where the results were highly significant $(\mathrm{p}<0.05)$ table 1 .

It was found that the mean difference between the groups $\mathrm{T} 1$ and $\mathrm{T} 2$; $\mathrm{T} 1$ and $\mathrm{T} 3 ; \mathrm{T} 2$ and $\mathrm{T} 3$ were highly significant $(\mathrm{p}<0.05)$ as shown in table 2 with $\mathrm{p}=0.000$. Heat-polymerized denture base material showed better bond strength results followed by light-polymerized denture base and injection-molded denture base materials.

Comparing the gap width between a silicone based permanent soft liner and different denture base resins by SEM analysis, the results show that there is significant difference in the mean gap width between the denture base materials $(\mathrm{p}<0.05)$ as seen in table 3 .

The mean gap width was compared, the results were not significant between G1 and G3 group as seen in table 4. A highly significant value was seen with gap width of G1 and G2; G2 and G3 groups ( $<<0.05)$. Heat-Polymerized denture base materials showed least gap width followed by injection-molded and light polymerized denture base materials respectively.

Table 1:-Comparison of tensile bond strength of different groups using One-way ANOVA.

\begin{tabular}{|c|c|c|c|c|}
\hline Tensile bond strength & Mean & Standard deviation & $\mathbf{F}$ & Sig. \\
\hline $\begin{array}{l}\text { Heat polymerized denture base } \\
\text { material (T1) }\end{array}$ & 2.4390 & .30935 & \multirow[t]{3}{*}{206.589} & \multirow[t]{3}{*}{$0.000($ H.S $)$} \\
\hline $\begin{array}{lll}\text { Injection molded denture base } \\
\text { material (T2) }\end{array}$ & .7490 & .09632 & & \\
\hline $\begin{array}{l}\text { Light polymerized denture base } \\
\text { material (T3) }\end{array}$ & 1.4200 & .01333 & & \\
\hline
\end{tabular}

Table 2:-Comparison of tensile bond strength of different groups using Post-hoc Tukey's test.

\begin{tabular}{|l|l|l|l|l|l|c|}
\hline Tensile bond strength & $\begin{array}{l}\text { Mean } \\
\text { difference }\end{array}$ & $\begin{array}{l}\text { Standard } \\
\text { error }\end{array}$ & Sig. & \multicolumn{2}{|l|}{$\begin{array}{l}\text { 95\% Confidence } \\
\text { Interval }\end{array}$} \\
\cline { 3 - 7 } & & & & $\begin{array}{l}\text { Lower } \\
\text { bound }\end{array}$ & $\begin{array}{l}\text { Upper } \\
\text { bound }\end{array}$ \\
\hline $\begin{array}{l}\text { Heat polymerized } \\
\text { denture base material } \\
\text { (T1) }\end{array}$ & $\begin{array}{l}\text { Injection molded denture } \\
\text { base material (T2) }\end{array}$ & 1.69000 & .08373 & $\mathbf{. 0 0 0}$ & 1.4824 & 1.8976 \\
\cline { 2 - 7 } & $\begin{array}{l}\text { Light polymerized denture } \\
\text { base material (T3) }\end{array}$ & 1.01900 & .08373 & $\begin{array}{l}\mathbf{. 0 0 0} \\
\text { (H.S) }\end{array}$ & .8114 & 1.2266 \\
\hline $\begin{array}{l}\text { Injection molded } \\
\text { denture base material } \\
\text { (T2) }\end{array}$ & $\begin{array}{l}\text { Light polymerized denture } \\
\text { base material (T3) }\end{array}$ & -.67100 & .08373 & $\begin{array}{l}\mathbf{. 0 0 0} \\
\mathbf{( H . S )}\end{array}$ & -.8786 & -.4634 \\
\hline
\end{tabular}

Table 3:-Comparison of gap width of different groups using One-way ANOVA.

\begin{tabular}{|l|l|l|l|l|}
\hline Gap width & Mean & Standard deviation & F & Sig. \\
\hline $\begin{array}{l}\text { Heat polymerized denture base } \\
\text { material (G1) }\end{array}$ & 7.8398 & .38357 & 3673.766 & $\mathbf{0 . 0 0 0}$ (H.S) \\
\cline { 1 - 3 } $\begin{array}{l}\text { Injection molded denture base } \\
\text { material (G2) }\end{array}$ & 24.0110 & .49684 & \\
\cline { 1 - 1 } $\begin{array}{l}\text { Light polymerized denture base } \\
\text { material (G3) }\end{array}$ & 8.3630 & .54366 & \\
\hline
\end{tabular}

Table 4:-Comparison of gap width of different groups using Post-hoc Tukey's test.

\begin{tabular}{|l|l|l|l|l|l|l|}
\hline \multicolumn{2}{|l|}{ Gap width } & $\begin{array}{l}\text { Mean } \\
\text { difference }\end{array}$ & $\begin{array}{l}\text { Standard } \\
\text { error }\end{array}$ & Sig. & \multicolumn{2}{|l|}{ 95\% Confidence Interval } \\
\cline { 4 - 7 } & $\begin{array}{l}\text { Lower } \\
\text { bound }\end{array}$ & $\begin{array}{l}\text { Upper } \\
\text { bound }\end{array}$ \\
\hline $\begin{array}{l}\text { Heat } \\
\text { polymerized } \\
\text { denture base }\end{array}$ & $\begin{array}{l}\text { Injection molded } \\
\text { denture base material } \\
\text { (G2) }\end{array}$ & -16.17120 & .21440 & $\mathbf{. 0 0 0}$ (H.S) & -16.7028 & -15.6396 \\
\hline
\end{tabular}




\begin{tabular}{|l|l|l|l|l|l|l|}
\hline material (G1) & $\begin{array}{l}\text { Light polymerized } \\
\text { denture base material } \\
(\mathrm{G} 3)\end{array}$ & -.52320 & .21440 & .054 (N.S) & -1.0548 & .0084 \\
\hline $\begin{array}{l}\text { Injection } \\
\text { molded } \\
\text { denture base } \\
\text { material (G2) }\end{array}$ & $\begin{array}{l}\text { Light polymerized } \\
\text { denture base material }\end{array}$ & 15.64800 & .21440 & $\mathbf{. 0 0 0}$ (H.S) & 15.1164 & 16.1796 \\
\hline
\end{tabular}

\section{Discussion:-}

Polymethyl methacrylate was introduced as a material for removable partial denture base and used in dental practice for more than 70 years, which has superior physical, biological and esthetic properties. The disadvantage of this material is unpleasant odor, contact allergies and difficulty in fabrication that includes flasking, boiling out, packing and water bath polymerization. In order to overcome these problems light-activated urethane dimethacrylate denture base resin was developed which has improved mechanical properties when compared with PMMA denture base polymers. With the advancement in polymer science, led to the development of new molding techniques that is, injection-molding technique. They have higher elasticity than heat polymerizing base resins (PMMA) and also better retention is obtained as they utilize the undercuts of abutment teeth by the retentive elements.

Soft liner materials are used on the intaglio surface of the denture to absorb some amount of energy produced by masticatory impact, which acts like a "shock absorber". The major requirement of this material are permanent resiliency, high dimensional stability, good adhesion to denture base, adequate tear resistance, non toxic, non irritating and incapable of sustaining fungal or bacterial growth. The major disadvantage of this material is that it is soft and has poor tear resistance and also bonding failure between the liner and denture base which creates a potential interface for microleakage resulting in delamination of the liner from the denture. The measurement of bond strength is very important as the adhesion failure between the lining material and denture base can create an environment for potential bacterial growth and accelerated breakdown of soft lining material.Finishing and polishing equally plays a role in the function and esthetics of the denture. Hence, the development of experimental long-term resilient liner material necessitates an evaluation of how well these materials can be polished and finished. The integrity of the junction after finishing and polishing needs to be evaluated as two materials polish differently.

Clinically, the ability of denture lining materials to resist debonding and internal fracture under masticatory stresses is extremely important.In the present study, the tensile test method was performed. This method was described by American society for testing and materials, and data obtained from such samples were found significant for testing the effectiveness of different processing techniques and adhesive systems.It is said that silicone rubber base material bond poorly to denture bases. Scanning electron microscopic examination of the interface reveals some information concerning the effect of various parameters on the bond between resilient liners and denture base materials along with the appearance of either a distant or a diffuse bonding at the interface.

\section{Conclusion:-}

Within the limitations of the study it is concluded that:-

1. Heat-Polymerized denture base resin has higher tensile bond strength to silicone based permanent denture soft liner Mollosil B.

2. The least gap width was noted in heat-polymerized denture base bonded to silicone based permanent denture soft liner Mollosil B.

Hence, Mollosil B soft denture liner bonds best to the heat-polymerized denture base material.

\section{References:-}

1. Tugut F, Cosun ME, Dogan DO, Kirmali O, Akin Hakan. Tensile bond strength between soft liners and two chemically different denture base materials: effect of thermocycling. J Prosthodont 2016 Jun;25(4):319-23.

2. Akin H, Tugut F, Guney U, Kirmali O, Akar T. Tensile bond strength of silicone-based soft denture liner to two chemically different denture base resins after various surface treatments. Lases med sci2013 Jan;28(1):119-23.

3. Hamanaka I, Shimizu H, Takahashi Y. Bond strength of a chairside auto polymerizing reline resin to injectionmolded thermoplastic denture base resins. Journal of prosthodontics research 2017;61(1):67-72. 
4. Hamanaka I, Shimizu H, Takahashi Y. Shear bond strength of an autopolymerizing repair resin to injectionmolded thermoplastic denture base resins. Acta Odontol Scand 2013 Sep;71(5):1250-4.

5. Machado C, Sanchez E, Azer SS, Uribe JM. Comparative study of the transverse strength of three denture base materials. J Dent 2007 Dec;35(12):930-3.

6. Diaz-Arnold AM, Vargas MA, Shaull KL, Laffoon JE, Qian F. Flexural and fatigue strengths of denture base resin. J Prosthet Dent 2008 Jul;100(1):47-51.

7. Ahmad F, Dent M, Yunus N. Shear bond strength of two chemically different denture base polymers to reline materials. J Prosthet Dent 2009 oct;18(7):596-602.

8. Razavi R, Khan Z, Fraunhofer JAV. The bond strength of a visible light-cured reline resin to acrylic resin denture base material. J Prosthet Dent 1990 Apr;63(4):485-7.

9. Lau M, Amarnath G S, Muddugangadhar B C, Swetha M U, Das K A A K. Tensile and shear bond strength of hard and soft denture relining materials to the conventional heat cured acrylic denture base resin; an in-vitro study. J of international oral health 2014 Dec;6(2):55-61.

10. Aydin A K, Terzioglu H, Akinay A E, Ulubayram K, Hasirci N. bond strength and failure analysis of lining materials to denture resin. Dental materials 1999 May;15(3):211-8.

11. Mese A, Guzel KG. Effect of storage duration on the hardness and tensile bond strength of silicone and acrylic resin-based resilient denture liners to a processed denture base acrylic resin. J Prosthet Dent 2008 Feb;99(2):153-9.

12. Mutluay M M, Ruyter I E. Evaluation of bond strength of soft relining materials to denture base polymers. Dental materials 2007 Nov;23(11):1373-81.

13. Kim BJ, Yang HS, Chun MG, Park YJ. Shore hardness and tensile bond strength of long-term soft denture lining materials. J Prosthet Dent 2014 Nov;112(5):1289-97.

14. Kulak-Ozkan Y, Sertgoz A, Gedik H. Effect of thermocycling on the tensile bond strength of six silicone-based, resilient denture liners. J Prosthet Dent 2003 Mar;89(3):303-10.

15. Mutluay M M, Ruyter E I. Evaluation of adhesion of chair side hard relining materials to denture base polymers. J Prosthet Dent 2005 Nov;94(5):445-52.

16. Mittal M, Kumar S A, Sandhu H S, Iyer S R, Ahuja R S. Comparative evaluation of the tensile bond strength of two silicone based denture liners with denture base resins. Medical journal armed forces India 2016 $\mathrm{Jul} ; 72(3): 258-64$.

17. Kawano F, Dootz ER, Koran A, Craig RG. Comparision of bond strength of six soft denture liners to denture base resin. J Prosthet Dent 1992 Aug;68(2):368-71.

18. Pinto JR, Mesquita MF, de Arruda Nobilo MA, Henriques GE. Evaluation of varying amounts of thermal cycling on bond strength and permanent deformation of two resilient denture liners. J Prosthet Dent 2003 Mar;89(3):303-10.

19. Mohammed SA, Hassen KS. Evaluation of some properties of four silicon based soft denture reliner materials. J Bagh Coll Dentistry 2011;23(2):36-42.

20. Khan Z, Martin J, Collard S. Adhesion characteristics of visible light-cured denture base material bonded to resilient lining materials. J Prosthet Dent 1989 Aug;62(2):196-200.

21. Pesun I J, Hodges J, Lai J H. effect of finishing and polishing procedures on the gap width between a denture base resin and two long-term, resilient denture liners. J Prosthet Dent 2002 Mar;87(3):311-8.

22. Radford DR, Watson TF, Walter JD, Challacombe SJ. The effects of surface machining on heat cured acrylic resin and two soft denture base materials: a scanning electron microscope and confocal microscope evaluation. $\mathbf{J}$ Prosthet Dent 1997 Aug;78(2):200-8.

23. Al-Athel M, Khier S. SEM assessment of the nature of the interface between molloplast-B and denture base materials. Saud Dent J 1997 sept;9(3):113-8.

24. Hamanaka I, Takahashi Y, Shimizu H. Mechanical properties of injection-molded thermoplastic denture base resins. Acta Odontol Scand 2011 Mar;69(2):75-9. 